\title{
Indigenous Education in Environmental Management and Conservation in Ghana: The Role of Folklore
}

\author{
Martin Q. Amlor \\ Centre for African and International Studies, University of Cape Coast, Cape Coast, \\ Ghana
}

Tel: 233-244-818-485Ｅ-mail: fmqamlor@yahoo.com

\begin{abstract}
Matthew Q. Alidza
Centre for African and International Studies, University of Cape Coast, Cape Coast, Ghana
\end{abstract}

Tel: 233-244-897-884Ｅ-mail: quarmelidza2014@yahoo.com

Received: April 10, 2016 Accepted: May 8, 2016 Published: June 30, 2016

doi:10.5296/jee.v7i1.9705 URL: http://dx.doi.org/10.5296/jee.v7i1.9705

\begin{abstract}
Studies into indigenous knowledge of African societies and their eco-system, and complemented by western research findings in recent years, point to a common fact that there is a complex interrelation between humans, animals, plants and their physical environment For this reason, Ghanaian societies enforce cultural laws that ensure protection and management of their natural resources. Despite the merits associated with African endowed natural environments, it is scary to note that to date, Ghana still faces serious environmental threats among which are: deforestation, annual bushfires, illegal surface mining, poor farming practices, unconventional methods of dumping human/industrial wastes and pollution of water bodies. This paper therefore attempts to investigate the causes of environmental degradation in Ghana and demonstrate how the people's folklore can contribute to ensuring a well-conserved environment that can benefit the country's present and future generations.
\end{abstract}

Keywords: Indigenous education, Environment, Management, Conservation, Folklore 


\section{Introduction}

A large section of traditional societies in Africa to date, still rely on indigenous knowledge passed on from generation to generation as they engage in agriculture and other activities which ensure their comfort and livelihood. Since knowledge about the environment is an internalised cultural phenomenon applied to ensure the existence and welfare of people, Ghanaian societies, for this reason, consider the environment as a living, breathing and dynamic being that reacts the same way as normal human beings do. The people also share the belief that attempts at destroying the environment has a rippling and a cruel effect on not only the people who destroy it, but also on all creatures/plants that depend on it for survival.

In the light of the above, there is the need to create awareness and education (both formal and informal) to spur on Ghanaians, to protect and conserve these natural habitats for posterity. In ensuring sustainable environmental awareness, protection and conservation in societies with high illiteracy rates, the UN agenda 21, chapter 36 stresses:

Education, (both formal and informal), public awareness and training should be recognised as a process by which human beings and societies can reach their fullest potential. Education is critical for promoting sustainable development and improving the capacity of the people to address environment and development issues. Both formal and informal education is crucial to changing people's attitudes so that they have the capacity to assess and address their sustainable development concerns.

\subsection{What is Environmental Conservation?}

Srikanth (2011:1) explains environmental conservation as the sustainable use and management of valuable natural resources which include plants, wildlife, water, fish, air, mineral deposits and preservation of forests. Since conservation satisfies the needs of humans in terms of their economic and health needs, they share the view that natural resources should be used wisely to prevent problems such as deforestation, air and water pollution, indiscriminate disposal of solid/liquid wastes, in order to maintain ecological balance that can support flora and fauna.

\section{Folklore Practice and the Environment}

Long before the coming of the Europeans, indigenous Ghanaian societies devised methods that protected their natural habitats through the enforcement of customary laws, taboos, stories, songs, riddles, proverbs and ritual performances collectively referred to as folklore. The Expert Committees of the UNESCO General Assembly of Technical and Legal experts on the safe guarding of folklore defines folklore as:

... a group oriented and tradition based creation of a group of individuals reflecting the expectations of the community as an adequate expression of its cultural and social identity, its standards and values are transmitted orally by imitation or by other means. Its forms include, among others, language, literature, music, dance, games, rituals, customs, handicrafts, architecture and art.

One of the best known explanations of folklore is found in Alan Dundes' brief essay, "What is 
Folklore?" Dundes disputes the notion that "folk" should be automatically identified with peasant or rural groups, or with people from the past. He argues that contemporary urban people also have folklore and suggests that rather than dying out, folklore is constantly being created and recreated to suit new situations (Dundes, 1965: 2). Dundes, therefore, provides a list of various types of folklore to demonstrate the large range of the field of study. His list includes the expected subjects of folktales, legends, myths, ballads, festivals, folk dance and song, but also offers examples of folklore that may not be as obvious, such as children's counting out rhymes, food recipes, house, barn and fence types, latrinalia (informal writings in public restrooms), as well as the sounds traditionally used to call specific animals.

Dundes (1965:3), stresses that his list is not exhaustive, but merely a sampling of the subjects that folklore scholarship can address, and which merit study for the insight that they provide into specific cultures. The list of fields covered by folklore can be expanded to include beliefs, customs, superstitions, proverbs, riddles, music/songs, myths, legends, tales, ritualistic ceremonies, magic, witchcraft, and all other manifestations and practices of primitive and illiterate people (Alidza, 2010). For a very long time, folklore in Africa had remained a rich source of indigenous knowledge. Not only did oral narratives such as folktales, proverbs, myths and riddles perform didactic functions, but they also serve as setting standards of behaviour to regulate the activities of the citizens as they explore their environments and natural resources.

\subsection{Folk music and the Environment}

Folk songs project individual and collective ideologies, histories and establish the identity of ethnic groups in the traditional societies of Ghana. Since the songs are avenues through which communities teach and transmit ecological knowledge, they are sung directly or incorporated into play games and storytelling for especially the youth who gather by the fire side after supper, to listen to. The elders create awareness during the narration of the stories about the natural environment, its origin and relationship with humans, plants and animals. Emphasis is, therefore, placed on ecological lessons that are drawn from song texts that talk about the benefits which human beings derive from co-existing with animals and plants for survival, hence, the need for humans also to reciprocate by protecting them.

The song below, and titled 'kpxda! wo vemevivits' (Look! you the greedy one), is sung in a call and response form to warn hunters with insatiable appetite for bush meat to desist from generating bush fires during hunting expeditions to catch rodents and other forest animals during the dry season. In a similar situation reported in the August 9, 2015 issue of the Gleaner, a Jamaica newspaper, Corey (2015) reports of careless hunters who illegally entered the forests of St. Andrew and St. Thomas to hunt for wild hogs as those responsible for the bush fires that destroyed about 405 hectares of forest reserves in May, 2015. He further quotes Damart Williams, an enforcement officer at the Department of Forestry, the agency charged with maintaining the country's forest resources: "in the process of hunting and being there overnight, these hunters set up camp sites with fires cooking and failure to put out the fires thoroughly results into wild bush fires which increase the chance of landslides due to runoff during rainfall, especially in areas where the hill sides are exposed". 


\section{Kpoda wo vem evivito}
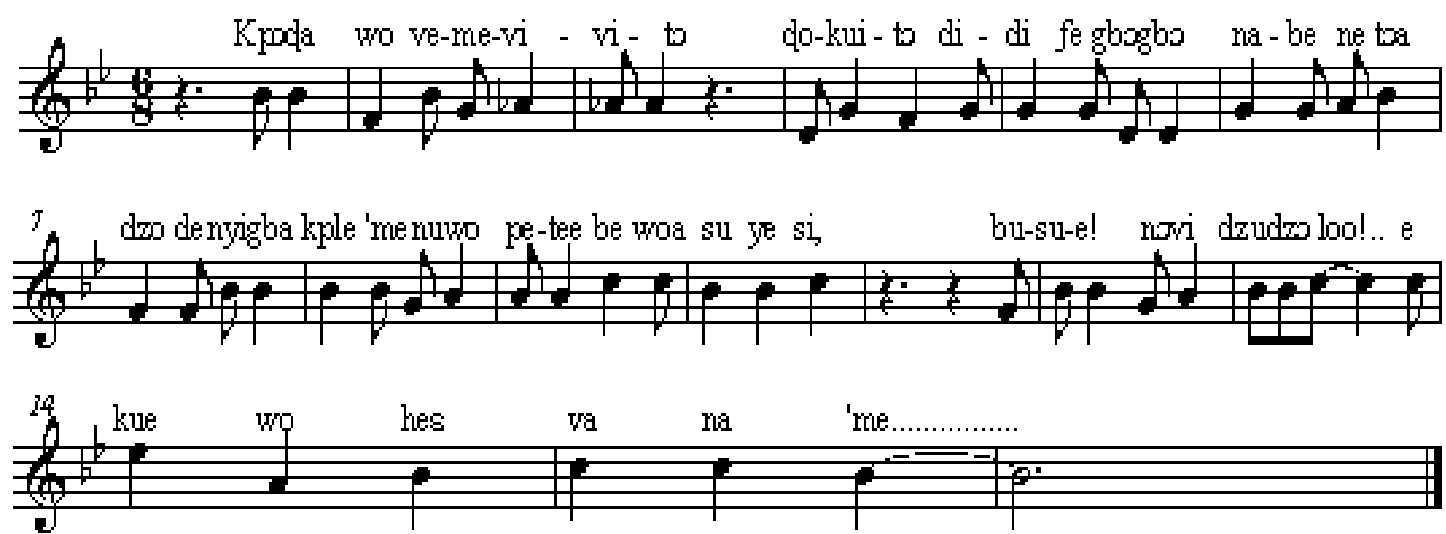

Example 1: A song warning smokers and hunters to stop destroying the environment with fire.

Kpoda, wo vemevivits,

Đokuitsdidi fe gbogbo nabe

Netsa 'dzo denyigba

Kple 'menuwo petee be

Woasu ye sia la, busue!

Dzudzo, ekue wohea vae n'ame
Look, you the greedy one'

Selfishness has driven you to the extent that

You set fire to the environment and

All what is within

For your personal greed, abomination!

Stop such attitude, for, it leads to death.

The songs, therefore, serve as motivators for learning and practicing good morals and also urge citizens to avoid environmental conservation offenses that the community eschews. Largely, environmental issues accompanied with appropriate song texts and guarded with complex laws, fear of punishment from the gods and spirits of the sacred forests and grooves, infuse discipline, unity, commitment and care for nature, serve as means of addressing the challenges that bedevil environmental protection and conservation in contemporary Ghana.

The song text below, admonishes citizens on the dangers of depleting forests and groves from where rivers take their sources:

Togbe Hosue gbls be,

Etsi, etsi, etsie ny'agbe

Etsidzotsofea, agbedzotsofee

Megafoa've, l'ati, atodzo gbe le tsidzof'o, Don't clear forests, fell trees or burn bush at

Busue, busue!

Labe tosisie mie na, he kua gbidigbidi
According to Hosu, the old grandfather,

Water, water, water is life

A source of water, is a source of life

Water sources, abomination, it's abomination!

Such activities dry up rivers completely.

\subsection{Challenges Facing Environmental Conservation in Ghana}

All the above folklore practices worked to perfection in the past since every individual was bound to strictly observe them. The result was a well-kept, a well-preserved and a well conserved environment with its attendant captivating and refreshing greenery. However, with the advent of "modernisation" and population explosion, there arose the need for what can generally be termed as a scramble for land, leading to extensive abuse of the environment. 
This paper attempts to demonstrate the challenges posed by deforestation, bush fires, the country's ever increasing population size, industrial and human wastes, water and atmospheric pollution to the environment in both urban and rural communities of Ghana, and to discuss how Ghanaian folklore and music can be used to address these challenges.

\subsubsection{Deforestation}

The Oxford Advanced Learner's Dictionary, $8^{\text {th }}$ edition, (2010:384), defines deforestation as "the act of cutting down or burning of trees in an area". By this action, the environment suffers some forms of degradation among which are: erosion of soils, decrease in biodiversity and destruction of the habitats plants and animals.

A paper titled, Resource Watch Agenda, ( $3^{\text {rd }}$ edition) and funded by Kasa, a civil society that seeks to improve natural resources and environmental governance (NREG) in Ghana, states that Ghana's forest depletion rate at 65,000 hectares per annum, points to a gloomy picture of forest extinction in the country. From 1909 - 1990, the country lost about 80\% of its forest cover and made communities in these areas poorer than before. The paper further notes:

For the most part, logging and mining have posed the most bothersome threat to Ghana's forests so that even her 200 forest reserves have not been left out. Officially, there are about 200 licensed timber companies operating in the country, which are under obligation to replant young trees as replacements in areas under their operation but majority of them do not carry out this associate responsibility (2010:5).

\subsubsection{Causes of Deforestation in Ghana}

European presence in the Gold Coast since the $15^{\text {th }}$ century brought about a Western type of monoculture which was the cultivation of vast acres of land for primary products and cash crops such as cocoa, coffee, and palm oil to feed their industries at home. Citing the causes of deforestation in South Africa, Noyoo (2007:169), notes: "there is a lot of commercial agriculture in the region predominantly dominated by white expatriates who applied to their cultivated crops, pesticides like DDT and fungicides which have adverse effect on the eco-system". In Ghana, local farmers were lured into adopting foreign farming methods that were opposed to indigenous agricultural practices such as mixed farming, bush fallowing and crop rotation which conserved the natural environment. Mumoki (2006:1) also states the causes of deforestation among folk communities of Kenya:

The high demand for land for infrastructural projects like construction of schools, hospitals, industries and roads as well as acquisition of land for crop cultivation, for wood, firewood, furniture and the quest for medicinal plants to treat health problems among others, have driven people on individual, organizational or governmental basis to destroy natural resources and the environment to the level we see today.

\subsubsection{Effects of Deforestation}

Gray (2008:1) observes that the destruction of rain forests leads to loss of plant and animal diversity as well as disrupting global climate patterns that give way to floods and droughts, animal torture and extinction. Kwarteng (2009:120) comments on the impact of deforestation 
on wildlife due to clearing of forest belts for cocoa cultivation in Ghana:

The rapid expansion of the cocoa industry in the forest belt of the country had drastic consequences on bio-diversity, particularly, the wildlife species..... and as such, an animal that suffered greatly from extensive cultivation of cocoa farms was the forest elephant (Loyodonta Africana Cyclotis). The acquisition of large tracts of forest lands for western influenced commercial agriculture was that the range or habitats of elephants were reduced to government constituted forest reserves......and this became a hindrance to the free movement and survival of the elephants and other wildlife species. The infringement on the habitat of the elephants made them to sporadically invade and destroy cocoa and food crop farms, settlements of farmers and, at times, killing some of the farmers.

Apusigah ascribes deforestation in Ghana to loggers who enter and destroy forests without effective replacement plans and multinational mining conglomerates have turned the earth surface and beneath, into burrows and exploit rich mineral deposits which hardly benefit the local communities and traditional authorities (2011:6). Other setbacks to proper management and conservation of the environment in both urban and rural communities of Ghana include bush fires, increasing population size, land, air and water pollution.

\subsection{Bush Fires and the Ghanaian Environment}

A bushfire is what I personally explain as a rapidly uncontrolled blaze of fire that spreads across and destroys flora and fauna. According to Londos (2011:1), a bush fire is a rapid and uncontrolled oxidation of a wooded and grassy area that results into strong flames that have the potential of causing physical damage through burning which affects global ecological systems. Most bushfires take place during the dry season when temperatures are high.

\subsubsection{Causes of Bush Fires}

The causes of bush fires can be described as natural and human influenced. Human influenced types are caused by small subsistence farmers who during burning weeds cleared to rid the land of debris for crop planting, are at times, unable to control the force of the fire which blows out of proportion and engulf large hectares of forests, food/cash crop farms and, as well, burn peasant settlements into ashes. Bushfires are also generated by farmers, hunters or individuals who satisfy their selfish desires by using fire and smoke to hunt for rodents such as grass cutter and rats out of their holes during the dry seasons and carelessly leave behind, little bits of amber that later develop into uncontrollable wild fires that destroy the eco-system. In other instances, bush fires are caused by either cattle herdsmen who set campfires to keep themselves warm at night, but do not properly put out these fires before heading elsewhere to graze their animals. While we can also attribute the cause of bushfires to smokers who irresponsibly discard pieces of smoked cigarette along forest or bush paths, one can also not rule out arsonists who deliberately cause bushfires to satisfy their own whims and caprices.

\subsubsection{Effects of Bush Fires}

From personal observations in the Volta, Eastern and the three northern regions of Ghana, the 
impact of bush fire on some communities of Ghana can be described as a double-edge sword because, it builds and destroys the environment as well. Londos, again states that one positive impact of bush fires on the forest vegetation in Australia is that the fires enable some plants such as the eucalyptus to open its seed pods to germinate and reproduce. Although fire serves many other useful purposes to humans in terms of cooking, generating heat, and clearing debris on farms to facilitate crop cultivation, Norgrove and Hauser (2014:1) argue that fire turns disastrous when it grows out of human control and destroys large hectares of forests, food/cash crop farms, livestock and peasant settlements.

\subsection{Ghanaian Population Size and the Environment}

One of the most serious problems which now accounts for continuous degradation of the environment in Ghana is rapid urban population growth which is currently extending gradually from the urban to the peri-urban communities. Rees, 1992, Rees and Wackernagel, (1994), comment on the problems of urban population:

Although, cities serve as 'engines' of growth in most developing countries by providing opportunities for employment, education, knowledge and technology transfer and ready markets for industrial and agricultural products, high urban populations place enormous stress on natural resources and imposes ecological stress whereby urban residents buy up prime agricultural lands for residential or commercial purposes. The conversion of farm lands and watersheds for residential purposes has negative effect on food security, water supply as well as the health of the people, both in the cities and in the peri-urban areas.

Amlor (2013:96), in his field interaction with some northern Ewe rural farmers in the Volta Region about easy access to land for farming purposes in Ghana, reports:

Peasant communities have no access to exclusively large plots of land for either food or cash crop cultivation. This is due to the fact that over population, technology, modernity and socio-economic conditions have seriously affected the inheritance system of the people. At present, it is a traditional requirement that a plot of land be shared among a deceased owner's children. As a result of implementing this traditional law, sizes of lands available to individuals are decreasing steadily. The ever-increasing population of the people has now led to more frequent tilling of the same small pieces of land, and thus, compounding soil infertility and degradation of the environment.

\subsection{Environmental Pollution}

A major aspect of environmental degradation, which is now gradually engulfing both urban and rural communities in Ghana, is pollution. Kemp defines environmental pollution as "the contamination of the physical and biological components of the earth/atmosphere system to such an extent that normal environmental conditions are adversely affected" (1998:129).

Pollution initially in Ghanaian societies was unheard of because prior to European presence, there were enough traditional land protection and conservation methods applied by the people to satisfy their social, religious and economic needs. However, European technological and industrial revolution which came with a high rate of pollution in the 19th century, negatively 
affected the sane environmental conditions which the societies first enjoyed. According to Nathanson (2014:1) air, water and land pollution were hastened by the establishment of industries and permanent housing settlements for large population of people in the city and urban areas. He further asserts:

Although environmental pollution can be caused by natural events such as forest fires and active volcanoes, the use of the word 'pollution', generally implies that the contaminants have an anthropogenic source, that is, a source created by human activities ever since groups of people first congregated and remained for a long time in any one place. Indeed, ancient human settlements are frequently recognized by pollutants in the form of heaps of rubble.

\subsubsection{Land/Water Pollution through Mining}

Awuah-Nyamekye and Sarfo-Mensah (2012:160), commenting on the benefits of mining in Africa, state: "as an industry, it has given society tremendous benefits. In terms of wealth creation, it is ranked amongst the highest income earners for many countries". However, the negative impact of mining in African countries like Ghana due to poor methods of mining has brought hardship to the local residents. Fertility of the land is now under threat due to reckless mining activities of government, private companies and the indigenes. Commenting on the negative activities of these various mining companies and the indigenous small-scale miners, Resource Watch Agenda (2010:5), an NGO newspaper remarks:

They are doing all within their power to mine in the forest reserves which they claim to abound in gold. Besides the forest areas subjected to mining activities in the Western and Ashanti Regions, Ajenua Bepo forest in the Brong Ahafo Region has recently been opened to mining by Newmont Ghana Company. In most of these mining activities, waste products have been poorly managed and toxic chemicals (cyanide) used in processing the minerals are released into the soil and water bodies which later give the local residents, health problems.

Toxic pollutions of this kind, according to the local residents increase health problems such as intestinal pains, keratosis, skin cancer, sleep disorders and salivation (Amankwah and Anim-Sackey, 2003). Multinational companies that operate in Ghana, place much interest on their profit margins than the environmental hazards that their actions cause.

At Tarkwa (a mining town) and its environs in the Western Region of Ghana, arsenic, cadmium and mercury are found in food crops such as cassava (manihot esculenta) and cocoyam (colocasia esculenta). Many families are now faced with lack of food and nutritional requirements either as a result of loss of their farm lands through direct government concessions to mining companies or through land degradation due to cyanide spillages, dumping of industrial wastes which negatively affect quality of food crops even produced.

On the local front, water pollution is caused by indigenes who engage in small-scale artisanal mining, locally referred to as galamsey. Activities of galamsey operators are reportedly leading to toxic chemical destruction of the land and pollution of the water bodies of the people. Hilson (2002b:54) describes the negative impact of small-scale mining on water 
bodies:

Mercury, used in excessive quantities in refining the minerals, is released uncontrollably into the natural ecosystems accumulating to toxic levels in soils, water bodies and destroying plant life. Perhaps, more important, however, is that small-scale mining as a migratory activity has caused a significant damage to the environment in Ghana. It is surprising to note that even though the Mercury Law (PNDCL, 217), Small-Scale Mining Law (PNDCL, 218) and Precious Mineral/Marketing Law (PNDCL, 219) were in existence since 1989, the enforcement of these laws fall below expectation.

\subsubsection{Pollution through Urban/Rural Waste}

An environmental hazard, which now poses a great danger to the health of Ghanaians, is generation and indiscriminate disposal of waste. Oluwade explains waste as refuse (empty cans, papers, rubbish etc), sewage (human excreta, water, urine) and industrial waste (chemical nuclear) being the by-products of certain substances manufactured or materials discarded to be properly disposed (2013:553). Observing the causes of urban and rural community pollution in Ghana, one cannot agree more with Okechukwu et al., when they state "the rapid, uncontrolled, unplanned urbanisation in the developing nations of Africa has brought untoward ill effect of environmental degradation. Indeed, one of the most pressing concerns of urbanization in the developing world has been the problem of solid, liquid and toxic waste management" (Okechuku, Norye-Nortey and Owusu-Agyei, 2012:146).

Floods and water pollution especially in the urban centres become worse when torrential rains which often occur in the months of June and July, get polluted with solid and liquid wastes which do not only claim human lives and property but also affect the health of the people. This habit of poor sanitation has given rise to heaps of uncontrolled garbage that litter roadsides and block drainage channels.

Disposal sites now constitute health hazard in the form of toxic wastes to people whose residences are nearer to the dumping sites. At present, there is rise in sanitation related diseases like malaria, schistosomiasis, river blindness, guinea worm, cholera, typhoid, hepatitis A, bilharzias, polio, hookworm and tape worm (Boadi et al., 2005).

\subsubsection{Air Pollution}

Air pollution is the contamination of the air through discharge of harmful substances such as toxicants and irritants that reduce the quality of air. In both urban and rural environments, air pollution is mainly attributed to human activities. In $21^{\text {st }}$ century Ghana, a smoke related business activity now thriving in the cities like Accra, Kumasi and Takoradi, and having a big toll on the country's climate and the environment, is wanton burning of electronic waste. 'E-wastes', a popular informal name for electronic products nearing the end of their useful life, are dumped by developed countries in Ghana. These discarded electronic gadgets which include old computers, photocopiers, fridges, and mobile phones, are made with hazardous materials such as heavy toxic metals, phthalates, and polyvinyl chloride. Since recycling these items in their countries of origin is not always a safe and easy option, they increasingly become part of the "throw away" culture of developed countries (Resource Watch Agenda, 
$3^{\text {rd }}$ Ed., 2010:4).

Agbogbloshie, a suburb of Accra, is the biggest dumping site of e-waste in Ghana. About one kilometer away from the site one can see thick clouds of smoke and fire as workers break, burn and melt electronic gadgets to recover valuable metals to be sold as scraps, they are exposed to smoke and a cocktail of harmful chemical substances (carcinogens and neurotoxins) which later cause health problems such as burning eyes, catarrh and abnormal breathing A research has revealed that within the next few years, this form of air pollution through the activities of the scrap dealers would finally expose Ghana to global warming and climate change that can lead to contracting various forms of diseases including skin cancer and cataract. (Resource Watch Agenda, $3^{\text {rd }}$ Ed., 2010:3). Speaking at a workshop in Kumasi, on climate change and adaptation strategy, Yaro (2010:1), a Ghanaian geography university lecturer, notes:

Over the next few years, global warming, a major cause of rising sea levels will increase Ghana's vulnerability to sea erosion, flooding and the incidence of earthquakes. According to him, geologists confirm the rise in sea levels which will further erode the coast line and cause movement of the sea further inland. Since Accra is the national capital, with so much investment, infrastructure and machinery, and the ministries with all government information, there will be great destruction and serious security implications with the rise in sea levels.

\section{The Way Forward}

The management and conservation of Ghana's environment are pressing issues that demand urgent attention now than before. It is thus, obligatory for every Ghanaian to acquire education on environmental preservation. In this vein, UN Agenda 21 (Chapter 36) states:

Education, both formal and informal, is widely used as a conservation intervention in order to develop positive attitudes, and it is often assumed that effective education will automatically lead to environmentally responsible behaviour. It is also critical for achieving environmental and ethical awareness, values and attitudes, skills and behaviour consistent with sustainable development and for effective public participation in decision-making. To be effective, environment and development education should deal with the dynamics of both physical/biological and socio-economic environment, human development, and should be integrated into all disciplines and, as well, employ formal and non-formal methods/effective means of communication.

Environmental education as a learning process, aims at increasing people's knowledge and awareness about the environment and its associated challenges (UNESCO, Tbilisi Declaration, 1978). It is thus, incumbent on the citizenry of Ghana to have knowledge about how their collective actions that can be channeled properly to salvage the country's ecosystem from total ruin.

\subsection{Folktales/Songs and Environmental Management and Conservation in Ghana}

With the apparent failure of modernization to help preserve the environment, there is the 
urgent need to refocus scholarship on African traditional values. The narration of folktales, accompanied with songs, is another avenue through which rural communities in Ghana can teach and transmit ecological knowledge. Story telling is used to connect with human experiences that are shared among members. For example, among the Ewes of Ghana, children learn through oral narratives as elders narrate educational stories often flavoured with music and dance while seated by the fire side in the evenings after supper. In the stories, fear and punishment are used as motivators to teach young ones the value of conducting themselves well and preserving the environment based on societal ethics.

In traditional African societies, there are traditional tales and taboos rendered in proverbs and wise sayings designed to protect the environment. Among the Ewe of Ghana, for example, the farmer is forbidden to cut down all trees on a piece of land cleared for planting crops lest the farm turns into a playing field for ghosts in the night. This, apart from the tree providing shade against direct sunshine, also ensures the conservation of flora. A typical Ewe proverb: "Ave bi dzo mexsa ame de agbe o" (a burnt forest does not protect or support human life) reminds people that for as long as we need protection from the forest, it must not be burnt. The observance of this proverb will always ensure that people guard against the wanton destruction of forests and, by extension, the environment.

\subsubsection{Folk Songs}

As indicated earlier, folk songs, couched in the language of a people, is an avenue through which the people conduct their lives socially, politically, economically and religiously. The songs also project individual and collective identities, ideologies, histories and establish their identity. Nzewi (1997) similarly describes some ways in which the Igbo of Nigeria use their folk music to establish their identity:

These music types, (variously or collectively) have the capability of emotional expression, aesthetic enjoyment, entertainment, communication, symbolic representation, physical response, enforcing conformity to social norms, validating social institutions and religious rituals, contributing to the continuity and stability of culture, protecting, conserving and integrating the society. While some feature incidentally in human activities, others are strung to ceremonies such as childbirth, incision/circumcision, installation, war, farming, festivals and funerals are core music events.

\subsubsection{Folk Song as a Didactic tool}

Apart from its entertaining value, folk songs inform and educate traditional societies on topical issues that affect them and their environment. The song texts, as vehicles that convey messages of the composer to the listeners, are of prime importance. An approach to informal education in Ghana on the causes of environmental degradation such as bush fires, deforestation through logging, pollution of land, air and water and how to protect and conserve the environment, must first begin with children in their young and formative years. Since they learn faster through songs laden with play activities, issues of environmental conservation should constitute themes of simple folk songs that can be composed, memorised and sung during their leisure times. The song texts should focus on rules and regulations, 
social values and norms, care for the environment as well as sanctions or punishments that go with negative human activities that degrade the environment. Similarly, Lssozi (2012:4), sees the value of informal environmental education as "a way of knowing the social etiquettes of the community and creating in the people, the awareness and sensitivity to issues of nature preservation, dissemination of knowledge on environmental conservation via stories, riddles, proverbs, taboos, songs as well as participation in sustainable resource use and other eco-friendly activities". Similarly, Olabimtan (1981:157) observed in some societies of Nigeria when he states that "indigenous songs perform the same role as the press and the radio, not only to inform, educate and entertain but also to express public opinion".

In an international forum on music as a vector for environmental awareness and conservation held in Geneva, Switzerland, by a group, 'Melody for Dialogue Among Civilisations Association' in alliance with UNESCO and UNEP on October 1, 2009, Angelique Kidjo, a Beninois and a Grammy award-winning music recording artiste declared by the Time Magazine, remarks:

In Africa where I come from, music and environment are inextricably linked. The arrival of the rains and harvests, the beauty and harshness of deserts, the splendor and fragility of our coasts, the greatness, richness and care for our forests were all passed down from generation to generation through music. I grew up fetching water from wells that were far away, searching for firewood, learning to survive during heat waves and droughts. For me, a healthy environment is a basic human right. I feel the responsibility to convey this simple but powerful message about care for the environment to people all over the world. I call on my fellow artistes to join me to endeavour to make a real difference for our generation and those who will inherit our beautiful planet. (http://www.unep.org/music_env/about.asp).

The above statement by Kidjo does not only portray music as a tool for conserving the environment but also, a means of promoting "survivalistic education", because it teaches individuals to adapt to the environment and explore means of survival. The song texts, which reflect the culture of which the people are part, show both simple and complex nature of the poetry. Merriam (1964:187) in this vein posits:

"one of the most obvious sources for the understanding of human behaviour in connection with music is the song text. Texts of course, are language behaviour rather the music sound, but they are integral part of music and there is clear-cut evidence that the language used in connection with music differs from that of ordinary discourse".

\subsubsection{Folk Songs as Repository of Societal Historical Data}

Similar to what obtains in many African societies, the cultural identity and traditional occupation of ethnic groups in Ghana such as Ewes, Akans, Gas and Dagombas are projected through historical accounts that are given through songs. Nketia (1974) sees historical songs, as one of the most important categories of genres in African societies that remind people of their past and their values. Historical song texts that focus on issues of the environment can 
be investigated and retrieved from non-literate local musicians and be re-packaged to inform modern environmental conservation demands.

There is the need to take pragmatic steps to promote the teaching of Ghanaian traditional work songs such as tofohawo (fishing songs), agblehawo (farming songs) and adevu, hunters' dance-drumming in the schools and rural communities as a way of educating the people to operate within their own social, economic and cultural realms. Some of the songs must also be used to discourage wanton destruction of the environment through bush fires and also highlight the negative impact of environmental degradation that lead to the extinction of certain animal species from our forests, rivers and the sea due to killing the young or the pregnant, pollution and its health risks associated with chemicals including DDT which are poured into the sea, rivers and other water bodies to catch fish and other marine animals.

\subsubsection{Folk Religious Music and the Environment}

Modum (1982:46) posits that religion; a universal phenomenon found in every human settlement, agitates the awareness of the people about super powers, whose spirits are reached during worship through music performed as instrumental, vocal, dance or a combination of two or all three forms. The music is believed to psyche the people to commune and enhance peaceful co-existence with the spirits, nature and the environment. Awuah-Nyamekye confirms the spirituality of the Akan; a large Ghanaian ethnic group and posits: "Akans believe that land, water, forests, grooves, animals and plants are not just factors of production but have their place within the sanctity of nature. To the people, any created entity that plays a crucial role in the survival of humans is regarded as sacred, hence, the reciprocal gesture of humans to preserve nature as well" (2014:50) The song below stresses the need to maintain good interrelation between humans and their environment in order to avoid the wrath of the Supreme Being and the spirits of the gods and ancestors.

\section{Menye Mawu Sogbolisa kple Detrowoe Wo Woa?}
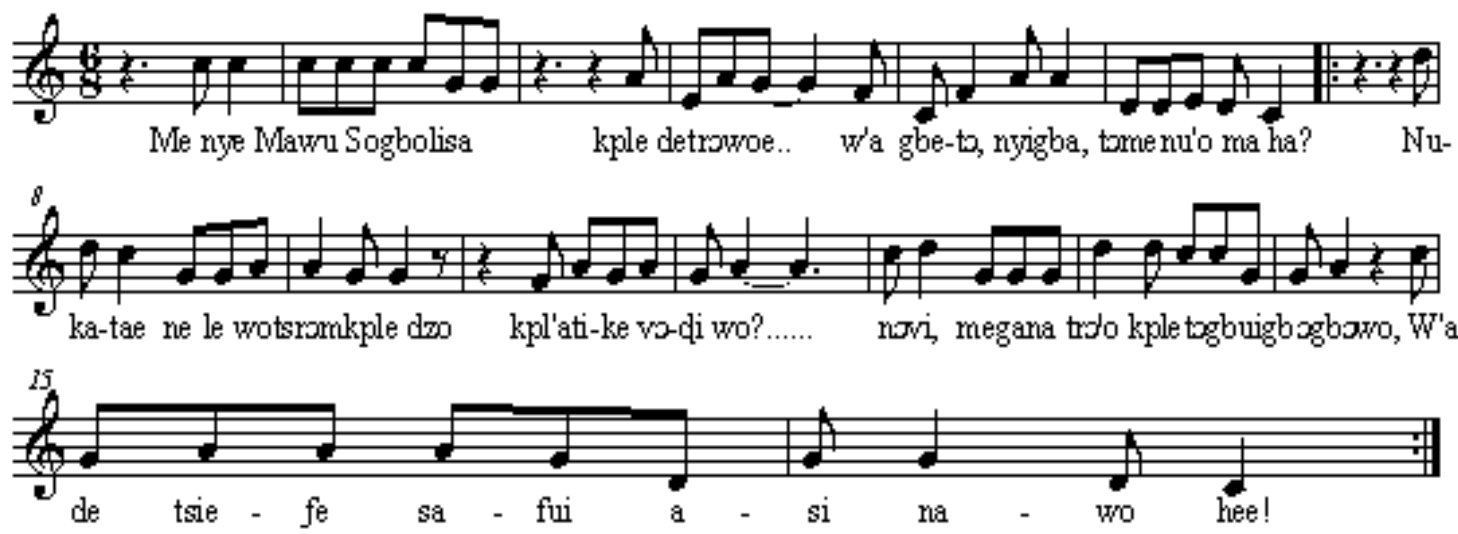

Example 2: A song on care for the environment to avoid anger and death from the gods.

Menye Mawu Sogbolisa kple de traawoe wo Gbets, 'nyigba kple tomenuwo maha?
Did the Supreme Being and gods of the land Not create creatures on the land and in rivers? 
'Leke nele wo tsrom kple dzo kpl'atike vadiwo? Why destroy them with fire and chemicals? Mega woe trowo kple togbuigbogboawo N'ade tsiefe safui asi nawo hee!

Don't irritate the gods and ancestors so that They hand over to you, the key of death.

\section{African Centred School Curriculum}

The lack of suitably designed Ghanaian-centred school curriculum, research and teaching methods and lack of qualified teachers to promote the teaching and learning of indigenous knowledge is a great setback to acquiring knowledge that satisfies Ghanaian needs and purposes. (Amlor 2015:305). Deliberate efforts should, therefore, be directed at integrating the study of environmental science into the curricula of basic, secondary and tertiary institutions. Topics treated must include poetry with themes on environmental care. Since children learn faster through songs, the song texts should be arranged in different tonal and rhythmic patterns similar to the present day Ghanaian rap music, to enable them memorise and sing these songs during their play games.

Public education on environmental management and conservation should also be studied at the secondary and tertiary levels through theatre, music, dance and drama and supported by short documentaries that can attract public broadcast on radio and television. In other words, the formal school system in Ghana should be refocused to produce a paradigm shift, away from theoretical education to one of practical application of foreign and local knowledge to address challenges that confront environmental management and conservation in Ghana. Supporting the need for environmental education through the use of folk music and drama, Con-Huyen (1979:143) stresses:

There is the need for societies to revive, learn and transmit messages in folk songs that specify in detail, warnings about environmental challenges, methods of crop cultivation, seasonal weather changes and adoption of precautionary measures that can ensure the safety of man and his environment. Folk songs, can serve as agricultural almanac; transmitting important information through generations of peasants (who can neither read nor write) on acceptable agricultural practices that neither deplete natural resources nor degrade the environment of the people.

Despite the impact of western education and technology on contemporary Ghana, the high rate of illiteracy among rural peasants who constitute the largest chunk of the country's population, can rarely ignore occupational folk music performance in their day to day activities. In this direction, one cannot agree more with Con-Huyen when he similarly comments on peasant work songs that relate to agriculture and the environment in Vietnam:

....until illiteracy is eradicated; it seems quite conceivable that folk songs will remain an effective avenue of communicating and recording information. But, even with a high literacy rate in future, folk songs may continue to play roles in communication, for, information on farming practices and the environment are more interesting, easier and faster to memorise when composed into traditional folk melodies regardless of whether they are transmitted through singing in the open fields or through modern media like radio or television" (1979:146). 


\section{Conclusion}

Ghana's biological diversity and how crucial it is to the sustenance of life of her citizens, plants and animals, cannot be overestimated. Despite the merits associated with endowed natural environments in Africa, it is scary to note that to date, Ghana faces serious environmental threats among which are: deforestation, bushfires, illegal surface mining, poor farming practices, unconventional methods of dumping human/industrial wastes, air, water and land pollution. The paper examined how Ghanaian folklore and music and traditions can collectively be used to address problems of environmental management and conservation in Ghana. It has therefore been observed that texts of Ghanaian folklore including indigenous songs have moral underpinnings that ensure conformity to social norms of the people: infusing discipline, instilling fear and sense of commitment to proper care and management of flora and fauna and their physical environments.

There should also be collaboration between the media, government, NGOs, traditional leaders as well as public and private companies to embark on educational campaigns, training programmes and seminars to create public awareness through radio/ television broadcasts and house-to-house campaigns that focus on eco-friendly agricultural practices that ensure a safe and healthy environment. By proper utilisation of their knowledge and eco-friendly farming technologies, rural communities would eventually enjoy well-managed and conserved environments that can enhance their income generation opportunities, improve their capacity for decision-making and uplift their overall development.

There is a critical need for government and university collaboration to mount environment-related courses that can train and turn out scholars and journalists with in-depth environmental education, to respond promptly to environmental issues through both print and electronic media. If practical considerations are given to the suggestions made, Ghana would eventually be transformed into a nation free of ignorance and irrationality.

\section{References}

Alidza, M. Q. (2010). The Repository of Indigenous Knowledge: Re-focusing Scholarship on African Cultural Practices. In Kuupole, D. D., \& De-Valera Botchway (Eds), Polishing the Pearls of Ancient Wisdom (pp. 119 - 130). Cape Coast: University of Cape Coast Press.

Amankwah, R. K., \& Anim-Sackey, C. (2003). Strategies for sustainable development of the small-scale gold and diamond mining industry of Ghana. Resources Policy, 29, 131-138

Amlor, M. Q. (2013). Agblehawo (Farmers' Music): Their Status and Impact on Farming Communities of Kpandu, Volta Region, Ghana. Unpublished PhD Thesis, University of Cape Coast.

Amlor, M. Q. (2015). Promoting indigenous knowledge for sustainable development in Africa: The case of Ghana. In Munyaradzi, M., \& Awuah-Nyamekye, S. (Eds.), Between Rhetoric and Realilty: The state and use of indigenous knowledge in Post-colonial Africa. Makon, Bamenda: Langaa Research \& Publishing CIG.

Apusigah, A. A. (2011). Indigenous Knowledge, Cultural Values and Sustainable 
Development in Africa. Paper Delivered at the $2^{\text {nd }}$ Annual Ibadan Sustainable Development Summit in Nigeria.

Awuah-Nyamekye, S., \& Sarfo-Mensah (2012). "Mining our heritage? Indigenous local people's views on industrial waste of mines in Ghana" In Kuan-Yeow Show and Xinxin Guo (eds) Industrial Waste in Ghana, 151-172, Rijeka, Croatia: ISBN: 978-953-51-0253-3, In Tech.

Awuah-Nyamekye, S. (2014). Indigenous ways of creating environmental awareness: A case study of Berekum traditional area. In Journal for the Study of Religion, Nature and Culture, 8(1), 46-63. Equinox Publishing Ltd.

Boadi, K.O., \& Kuitunen, M. (2005). Environment, wealth, inequality and the burden of disease in the Accra metropolitan area, Ghana. International Journal of environmental health research, 15(3), 193-206.

Cong-Huyen, N. T. (1979). Functions of Folk Songs. In Vietnam'in Blacking J., \& Kealinohomoku (Eds.), The Performing Arts: Music and Dance. The Hague \& N.Y.

Corey, Robinson (2015). Wild dog hunters linked to bush fires. [Online] Available: http://jamaica-gleaner.com/article/news/20150809/wild-hog-hunters-linked-bush-fires (August 9, 2015)

Dundes, A. (1965). The Study of Folklore, New Jersey: Prentice Hall, Inc.

Gray, I. (2008). Tropical Rainforests and Animals. [Online] Available: http://www. tropicalrainforest animals.com.

Hilson, G. (2002b). Promoting sustainable development in Ghanaian small-scale mining operations. Environmentalist, (22), 55-57.

Kemp, D. D. (1998). The Environment Dictionary. London: Routledge, p. 129. [Online] Available: http://www.Questia.com

Kidjo, A. (2009). Music as a vector for environmental awareness. [Online] Available: http://www.unep. org/music_env/about.asp. (March 13, 2015).

Kwarteng, K. O. (2009). The Gold Coast Ivory exports during the colonial era, 1875-1932. In Drumspeak, International Journal of Research in Humanities, 2(2), 120. Cape Coast University Press, Cape Coast.

Londos, C (2011). Impact of bush fires. [Online] Available: http://bushfiresaustralia.tumblr com/ impacts.

Lssozi, L. (2012). Values of Participation: The role of culture in nature preservation and environmental education among the Baganda. Available at http://www.jsedimensions.org. Retrieved: May 21, 2015

Mbiti, J. S. (1991). Introduction to African religion (2nd Ed). Heinemann Educational Publishers, OX2 8EJ. 
Merriam, A. P. (1964). Anthropology of Music. Bloomington: N. Western University Press.

Modum, E. P. (1982). Gods as Guests: Music and festival in African traditional Societies. In O.U. Kalu (Ed.), African Cultural Development Readings in African Humanities (pp. 45-47). Enugu: Forth Dimension Publishing Co. Ltd.

Mould-Iddrisu, B. (1997). Preservation and Conservation of Expressions of Folklore: the Experience of Africa. Paper prepared for UNESCO-WIPO World Forum on the Protection of Folklore. April 8 - 10, 1997.

Mumoki, F. (2006). The effects of deforestation on our environment today. [Online] Available: http://www.tigweb.org/youth-media/panorama/article.html.

Nathanson, J. A. (2014). Pollution. [Online] Available: http://www.britannica.com/EBchecked/topic/468070/pollution.

Nketia, J. H. (1974). The Music of Africa. London: Victor Gollancz Ltd.

Norgrove \& Hauser (2014). Estimating the consequences of fire exclusion for food production, soil fertility and fallow recovery in shifting cultivation landscapes in humid tropics. Journal of Environmental Management. Vol. 55, No. 3(9536-549).

Noyoo, N. (2007). Indigenous Knowledge Systems and their Relevance for Sustainable Development: A Case of Southern Africa.in Journal of Tribes and Tribals, 1, 167-172.

Nzewi, M. (1997). African Music: Theoretical Content and Creative Continum: The Culture Exponent's Definitions. Oldershausen, Germany: Institut fur Didaktik Popularer Musik.

Okechukwu, K., Kayode, \& Okufuwa, O. A. (2013). Perceived health consequences of indiscriminate waste disposal by the market women. Mediterranean Journal of Social Sciences. MCSER Publishing, Rome, Italy.

Olabimtan, A. (1981). The Ife/Gelede poet of Egbado Ketu Yoruba. In U. N. Abalagu et. al (ed.), Oral Poetry in Nigeria (pp. 151-165). Lagos: Nigeria Magazine.

Oluwade, P. A. (2013). A guide to tropical environmental health and engineering. A publication of Nigerian Social Institute

Oxford Advanced Learner's Dictionary. (2010). 8th Ed. Oxford University Press.

Rees, W. (1992). Ecological footprints and appropriate carrying capacity: What urban economies leave out. Environment and Urbanisation, 4(2), 121-129.

Rees, W., \& Wackernagel, W. (1994). Ecological footprints and appropriate carrying capacity". In Investing in natural capacity: The ecological economics approach to sustainability. Washington D.C.

Resource Watch Agenda, (2010). Ghana's forests and natural resources in crises. Published by Public Agenda, Ghana.

Srikanth, R. (2011). Conservation of the environment. [Online] Available: 
http://www.wikinut $>$ News $>$ Environment.

UN Agenda 21 (chapter 36): Promoting education, public awareness and training. [Online] Available: http://www.un.org/esa/dsd/agenda21/res_agenda21_36.shtml.

UNESCO Tbilisi Declaration. (1978). Environmental education and the role of the media. [Online] Available: http://faqexplorer.com/.

Yaro, J. A. (2010). Climate change must be arrested" in the $3^{\text {rd }}$ Edition of the February 2010 issue of the Resource Watch Agenda, pp. 1-2.

\section{Copyright Disclaimer}

Copyright for this article is retained by the author(s), with first publication rights granted to the journal.

This is an open-access article distributed under the terms and conditions of the Creative Commons Attribution license (http://creativecommons.org/licenses/by/3.0/). 